\title{
PENTINGNYA PENGARSIPAN ARSIP PEMILU \\ DALAM MENUNJANG PEMILU YANG JUJUR DAN ADIL
}

(The Importance of Archiving Election archive's in order to support Honest and Fair Election)

\author{
Benedictus Sahat \\ Badan Pembinaan Hukum Nasional Kementerian Hukum dan HAM RI \\ Jl. Mayjen Sutoyo - Cililitan Jakarta Timur \\ Email : b3nny_hut@yahoo.com \\ Naskah diterima: 26 Maret 2014; revisi: 14 April 2014; disetujui: 29 April 2014
}

\begin{abstract}
Abstrak
Pelaksanaan Pemilu dalam perjalanannya bukan tanpa permasalahan, kompleksitas permasalahan sering kali muncul pada setiap tahapan Pemilu, salah satu permasalahan yang muncul tetapi sering luput dari pengamatan adalah mengenai pengarsipan, oleh karena itu melalui penelitian ini mengangkat peran pengarsipan arsip Pemilu dalam menunjang pelaksanaan Pemilu yang demokratis, yang kemudian menginventarisir kelemahan pengarsipan arsip Pemilu saat ini, dan menganalisa tolak ukur pengarsipan yang baik bagi Pemilu. Melalui studi kepustakaan penelitian ini memiliki kesimpulan bahwa pengarsipan memiliki peran penting dalam menunjang proses Pemilu yang demokratis, karena sebagai salah satu bentuk kontrol atas jalannya Pemilu, di samping itu dokumen yang telah diarsipkan dapat menjadi alat bukti yang sah dan otentik. Oleh sebab itu manajemen arsip yang baik dan pengintegrasian dengan teknologi informasi secara nasional dan terpadu ke dalam arsip elektronis yang komprehensif akan meningkatkan keamanan dan kemudahan pengaksesan data Pemilu secara cepat, otentik dan akurat oleh masyarakat.
\end{abstract}

Kata Kunci: Arsip, Pemilu, Demokratis

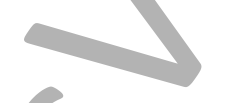

\section{Abstract}

Progress of election as long as its journey not without causing many problems. Problems complexity comes in any grade of election, one of problems comes to surface but often unseen from our vision is archives, This research want to lift up the role of archives in election records in order to support democratically election then to classify weaknesses of election archives nowadays and to analyze the indicator of good archives for the election. Through library research this research described that archives have important role in order to support democratically election, as its function as control mechanism to the election, besides all the documents can be authentic and original prove if there any disputes in election. Since regularly archives management with integration to information technology national widely and integrated to comprehensive electronically archives will increase secure and easy to access of election documents fast, authentic and accurate by society. Keywords: Archives, Election, Democracy 


\section{A. Pendahuluan}

Negara Republik Indonesia merupakan negara demokrasi, hal ini tercermin dengan peletakan kedaulatan rakyat sebagai kedaulatan tertinggi yang direpresentasikan melalui penempatan wakil-wakil rakyat (house of representative). Melalui mekanisme pemilihan umum (Pemilu) itu lah yang akan menetapkan para wakil-wakil rakyat pada kursi perwakilan, oleh sebab itu pelaksanaan Pemilu menjadi penting dan sakral dalam mewujudkan nilainilai demokrasi bagi suatu Negara, karena setiap warga negara telah mempercayakan aspirasinya kepada para wakilnya dan warga negara memiliki tanggung jawab, kedaulatan, dan hak untuk menentukan pemimpin secara demokratis.

Sebuah negara bisa disebut demokratis jika didalamnya terdapat mekanisme pemilihan umum yang dilaksanakan secara berkala atau periodik untuk melakukan sirkulasi elit. Sedangkan menurut Rizkiansyah Pemilihan umum adalah salah satu pranata yang paling representatif atas berjalannya demokrasi, tidak pernah ada demokrasi tanpa Pemilihan Umum. ${ }^{1}$

Melalui undang-undang Nomor 8 Tahun 2012 tentang Pemilihan Umum Anggota Dewan Perwakilan Rakyat, Dewan Perwakilan Daerah dan Dewan Perwakilan Rakyat Daerah, telah dibentuk sistem informasi data Pemilih yang berisi data Pemilih secara nasional yang wajib dipelihara dan dimutakhirkan oleh Komisi Pemilihan Umum Kabupaten/Kota agar dapat digunakan dalam Pemilu selanjutnya hal ini sebagaimana tercantum dalam penjelasan undang-undang tersebut sehingga bagi warga negara Indonesia yang belum terdaftar sebagai pemilih diatur dengan jaminan hak memilih dengan menggunakan bukti kartu tanda penduduk atau paspor.

Pemilu yang dilaksanakan di Indonesia berlandaskan asas: mandiri, jujur, adil, kepastian hukum, tertib, kepentingan umum, keterbukaan, proporsionalitas, profesionalitas, akuntabilitas, efisiensi, dan efektivitas, ${ }^{2}$ maka pemerintah membentuk Komisi Pemilihan Umum (KPU) dimana KPU bersifat nasional tetap dan mandiri (Pasal 22E ayat 5 UUD 1945). ${ }^{3}$

Semangat KPU sebagai lembaga negara yang bertanggungjawab sebagai penyelenggara pemilu yaitu: melayani hak konstitusional warga negara baik sebagai pemilih maupun peserta pemilu, mencapai sinergitas KPU dan Bawaslu dalam kerangka check and balances untuk meyelesaikan masalah yang muncul disetiap tahapan.

Tugas dan kewenangan KPU sebagaimana yang tercantum dalam Pasal 10 Undang-Undang Nomor 3 Tahun 1999 tentang Pemilihan Umum adalah: ${ }^{4}$

Rizkiansyah, Mengawal Pemilu Menatap Demokrasi (Bandung: Idea Publishing, 2007), hlm. 3.

Undang-Undang Nomor 15 Tahun 2011 tentang Penyelenggaraan Pemilu. (Lembaran Negara Republik Indonesia Nomor Tahun 2007 Nomor 59. Tambahan Lembaran Negara Republik Indonesia Nomor 4721).

3 Sifat nasional mencerminkan bahwa KPU memiliki wilayah kerja dan tanggung jawab mencakup seluruh wilayah Negara Kesatuan Republik Indonesia. Sifat tetap menunjukkan KPU sebagai lembaga yang menjalankan tugas secara berkesinambungan meskipun dibatasi oleh masa jabatan tertentu. Sifat mandiri menegaskan KPU dalam menyelenggarakan Pemilihan Umum bebas dari pengaruh pihak mana pun.

4 Lihat Pasal 10 Undang-Undang Nomor 3 Tahun 1999 tentang Pemilihan Umum dan Pasal 2 Keputusan Presiden Nomor 16 Tahun 1999 tentang Pembentukan Komisi Pemilihan Umum dan Penetapan Organisasi dan Tata Kerja Sekretariat Umum Komisi Pemilihan Umum. 
1. Merencanakan dan mempersiapkan pelaksanaan Pemilihan Umum;

2. Menerima, meneliti dan menetapkan Partaipartai Politik yang berhak sebagai peserta Pemilihan Umum;

3. Membentuk Panitia Pemilihan Indonesia yang selanjutnya disebut PPI dan mengkoordinasikan kegiatan Pemilihan Umum mulai dari tingkat pusat sampai di Tempat Pemungutan Suara yang selanjutnya disebut TPS;

4. Menetapkan jumlah kursi anggota DPR, DPRD I dan DPRD I| untuk setiap daerah pemilihan;

5. Menetapkan keseluruhan hasil Pemilihan Umum di semua daerah pemilihan untuk DPR, DPRD I dan DPRD II;

6. Mengumpulkan dan mensistematiskan bahan-bahan serta data hasil Pemilihan Umum;

7. Memimpin tahapan kegiatan Pemilihan Umum;

8. Tugas dan kewenangan lainnya yang ditetapkan dalam Undang-undang Nomor 3 Tahun 1999 tentang Pemilihan Umum. (Sedangkan dalam Pasal 11 Undang-undang Nomor 3 Tahun 1999 tersebut ditambahkan juga, bahwa selain tugas dan kewenangan KPU sebagai dimaksud dalam Pasal 10, selambat-lambatnya 3 (tiga) tahun setelah Pemilihan Umum dilaksanakan, KPU mengevaluasi sistem Pemilihan Umum).

Dalam tugas dan wewenang KPU seperti tersebut di atas, jelas menunjukan core bisnis KPU meliputi: perencanaan, regulator, pemuktakhiran data pemilih, verifikasi peserta Pemilu, pengelolaan logistik, pemungutan dan perhitungan suara, menetapkan hasil Pemilu, penegakan hukum administrasi Pemilu, sosialisasi dan evaluasi. Yang mana peran KPU pusat sebagai regulator dan KPU propinsi dan kabupaten kota sebagai koordinator. ${ }^{5}$

Pemilu 2014 diharapkan sebagai Pemilu yang jujurdanadilsertadapatdipertanggungjawabkan sehingga akan membawa perubahan di berbagai bidang kehidupan bernegara termasuk pelayanan terhadap kesehatan, pendidikan, dan peningkatan kesempatan kerja, dan tidak terlalu di dominasi kepentingan politik partai yang dikuasai segelintir orang.

Pelaksanaan Pemilu dalam perjalanannya bukan tanpa permasalahan, kompleksitas permasalahan acap kali muncul pada setiap tahapan Pemilu, salah satu permasalahan yang muncul tetapi sering luput dari pengamatan adalah mengenai pengarsipan, karena keakuratan data pada arsip serta otentikasi dokumen Pemilu harus selalu dijaga yang sewaktu-waktu dapat digunakan sebagai bukti bagi para pihak terkait.

Fungsi pengarsipan bagaikan sekeping uang logam yang bermuka dua kebelakang bersifat statis (archives), dan kedepan bersifat dinamis (records) sesuai dengan simbol Dewan Kearsipan Internasional (International Council of Archives) di Perancis, yang menggunkan simbol Janus dewa Yunani berwajah dua. Jika mencermati definisi arsip menurut Ketentuan Umum Undang-Undang Nomor 43 Tahun 2009 tentang Kearsipan disebutkan bahwa arsip adalah rekaman kegiatan atau peristiwa

Idha Budiarti, "Sistem dan Pelaksanaan Pemilu Anggota DPR, DPD dan DPRD Tahun 2014", (makalah disampaikan pada kegiatan CLE Badan Pembinaan Hukum Nasional, Jakarta, 18 Februari 2014), hlm. 6. 
dalam berbagai bentuk dan media sesuai dengan perkembangan teknologi informasi dan komunikasi yang dibuat dan diterima oleh lembaga negara, pemerintahan daerah, lembaga pendidikan, perusahaan, organisasi politik, organisasi kemasyarakatan, dan perseorangan dalam pelaksanaan kehidupan bermasyarakat, berbangsa, dan bernegara. Dalam Undangundang tersebut terdapat perluasan pemaknaan mengenai arsip termasuk di dalamnya mengenai dokumen elektronik, demikian juga terhadap bidang kearsipan yang semakin meluas tidak hanya lembaga pemerintah dan pemerintah daerah tetapi juga Partai Politik.

Salah satu contoh masalah kearsipan Pemilu adalah pengelolaan kearsipan terhadap surat suara. Sebagai contoh yang pernah dikeluhkan oleh Tjahjo Kumolo sekjen DPP partai PDI Perjuangan, dimana arsip pada Pemilu 2009 terhapus sehingga partainya tidak bisa mendapat dokumen tersebut baik dalam Pemilu legislatif maupun Pemilu presiden. Padahal menurutnya Partainya sebagai peserta Pemilu berhak untuk ikut mengontrol jalannya Pemilu (termasuk soal percetakan kertas suara, berapa yang terpakai dan dan berapa yang tersisa dan ini tidak dapat diketahui). Kemudian pada kasus lain mengenai pengarsipan Pemilu adalah hilangnya arsip dan data Pemilu yang terjadi di Jawa Timur tepatnya Kabupaten Malang, dimana George Da Silva seorang anggota Pengawas Pemilu Divisi Penanganan Penindakan dan Pelanggaran Pemilu Kabupaten Malang, Jawa Timur, mengalami kehilangan data yang terdapat dalam laptop yang berisi informasi yang sangat penting berupa bukti- bukti pelanggaran yang dilakukan Partai Politik sejak Desember 2012 sampai dengan Desember 2013, klarifikasi pelanggaran, hasil kajian dan laporan ke Polres Malang oleh Parpol, Caleg, dan anggota DPRD Propinsi Jawa Timur. ${ }^{6}$

Kurang tersedianya SDM yang memahami pengelolaan kearsipan juga merupakan salah satu kendala dalam optimalisasi fungsi arsip. Di Komisi Pemilihan Umum dan Panitia Pengawas Pemilu baik di Kabupaten/Kota, belum terdapat sistem pengarsipan yang baku sehingga menyebabkan kurang tertatanya pengarsipan Pemilu yang sebenarnya sangat penting.

Untuk itu perlu memasukan pengarsipan Pemilu ke dalam sistem termasuk juga mengenai Jadwal Retensi Arsip (JRA) karena arsip Pemilu merupakan memori/rekaman kolektif proses pemilihan umum yang telah berlangsung.

Oleh sebab itu melalui kajian ini diharapkan mampu menunjukan bahwa pengarsipan Pemilu merupakan hal yang penting dan krusial dalam menjaga proses demokrasi di Indonesia.

\section{B. Permasalahan}

Dari latar belakang yang telah diuraikan pada pendahuluan di atas, maka penulis ingin mengangkat beberapa permasalahan yaitu:

1. Bagaimana peran pengarsipan arsip Pemilu dalam menunjang pelaksanaan Pemilu yang demokratis?

2. Bagaimana kelemahan pengarsipan arsip Pemilu saat ini, dan tolak ukur pengarsipan yang baik bagi Pemilu? 


\section{Metode Penelitian}

Berdasarkan permasalahan di atas, penelitian ini dilakukan dengan menggunakan studi kepustakaan untuk mencari jawaban atas permasalahan yang ada. Data yang terkumpul dihubungkan satu sama lain melalui studi kepustakaan (library research), dikaji, diinterpretasi dan dianalisa untuk selanjutnya ditarik kesimpulannya.

Studi kepustakaan merupakan langkah yang penting dimana setelah seorang peneliti menetapkan topik penelitian, dan langkah selanjutnya adalah melakukan kajian yang berkaitan dengan teori yang berkaitan dengan topik penelitian. Dalam pencarian teori, peneliti akan mengumpulkan informasi sebanyakbanyaknya dari kepustakaan yang berhubungan. Sumber-sumber kepustakaan dapat diperoleh dari: buku, jurnal, majalah, hasil-hasil penelitian (tesis dan disertasi), dan sumber-sumber lainnya yang sesuai (internet, koran dan lain-lain). ${ }^{7}$

\section{Pembahasan}

\section{Peran Pengarsipan Arsip Pemilu dalam Menunjang Pelaksanaan Pemilu Yang Demokratis}

Pemilu yang demokratis sesungguhnya merupakan cerminan pemenuhan kedaulatan oleh negara terhadap rakyatnya. Kedaulatan sendiri merupakan ciri yang dimiliki sebuah negara dan hal inilah yang membedakannya dengan bentuk persekutuan lainnya. Istilah kedaulatan pertama kali diperkenalkan oleh Jean Bodin ia menggunakan istilah "souveranaite", yang menyatakan kedaulatan bersifat imperatif dan wajib sebagai syarat eksistensi suatu negara.

Menurut Abdurrahman Wahid demokrasi merupakan keharusan yang wajib dipenuhi bukan saja karena demokrasi sangat memungkinkan terbentuknya pola interaksi dan relasi politik yang "equal" tetapi juga sangat mendukung pluralisme bangsa. Adapun ciri pemerintahan demokratis yaitu: ${ }^{8}$

a. Adanya Partai Politik yang melalui proses Pemilu yang langsung, umum, bebas dan rahasia dan secara keseluruhan mempunyai dukungan luas di masyarakat.

b. Adanya Konsensus atau Persetujuan Umum mengenai aturan main politik (aturan dan proses pengambilan keputusan)dan konsensus mengenai nilai-nilai ekonomi, sosial, dan budaya yang ingin dicapai atau dipertahankan oleh masyarakat.

c. Terdapat lembaga eksekutif yang dominan atau menetukan dalam pengambilan keputusan pemerintahan.

d. Birokrasi negara yang mampu melaksanakan kebijaksanaan pemerintah.

Guna mewujudkan Pemilu yang memiliki nilai-nilai demokratis diperlukan sistem Pemilu yang jujur dan adil. Menurut Ben Reilly, sistem Pemilu dirancang untuk memenuhi tiga hal yang tidak terpisahkan satu sama lain, yaitu: menterjemahkan jumlah suara yang diperoleh dalam Pemilu menjadi kursi di badan legislatif; wahana penghubung yang memungkinkan rakyat dapat menagih tanggungjawab wakilwakil yang telah mereka pilih; memberikan

Nazir, Metode Penelitian (Jakarta: Rineka Cipta, 1998), hlm. 112.

8 R William Liddle, Pemilu-Pemilu Orde Baru: Pasang Surut Kekuasaan Politik (Lembaga Penelitian, Pendidikan dan Penerangan Ekonomi dan Sosial, 1992), hlm. 143. 
insentif kepada mereka yang memperebutkan kekuasaan untuk menyusun imbauan kepada pemilih dengan cara berbeda-beda. ${ }^{9}$

Salah satu bentuk kontrol terhadap pelaksanaan Pemilu tersebut adalah evaluasi terhadap sistem kearsipan yang secara tidak langsung akan mempengaruhi proses Pemilu yang demokratis, sistem pengarsipan yang baik yang telah dilakukan SIAR (Sistem Informasi Kearsipan) mendapat perhatian yang besar oleh KPU.

Selain sebagai sarana kontrol Pemilu, proses pengarsipan arsip Pemilu juga menempatkan arsip sebagai alat bukti yang sah, karena salah satu tujuan penting dari penyelenggara pengarsipan adalah: "Menjamin ketersediaan arsip yang otentik dan terpercaya sebagai alat bukti yang sah", hal ini sesuai dengan Undang-Undang Nomor 43 Tahun 2009 tentang Kearsipan dalam Pasal 3 huruf $b$.

Arsip surat suara yang telah dicoblos mendapat perhatian yang besar dan mendapat penjagaan yang ketat karena, hal ini merupakan rekaman sejarah negara yang perlu diketahui masyarakat baik sekarang maupun untuk masa mendatang (termasuk berguna dalam bidang penelitian yang dilakukan masyarakat luas, maupun para praktisi). Arsip Pemilu juga akan sangat membantu mengusut peristiwa bilamana terjadi kecurangan dalam proses Pemilu, sebab tidak jarang partai peserta Pemilu mengharapkan perhitungan ulang apabila dirasa ada kecurangan atau keanehan yang terjadi, selain itu juga arsip Pemilu merupakan layanan informasi publik kepada masyarakat.

Dalam upaya penyelamatan arsip Pemilu, Kepala Arsip Nasional telah membuat regulasi yang mengatur kewenangan, telah dikeluarkan Peraturan Kepala Arsip Nasional tentang Pedoman, Penataan dan Penyimpanan Arsip/ Dokumen Pemilihan Umum. Pedoman Pendataan, Penataan Dan Penyimpanan Dokumen/Arsip Pemilu dipergunakan sebagai acuan bagi Lembaga yang berkaitan dalam penyelenggaraan Pemilu dan Lembaga Kearsipan tingkat pusat maupun daerah dalam rangka melaksanakan pendataan, penataan, dan penyimpanan dokumen/arsip Pemilu. ${ }^{10}$

Dalam bidang kearsipan adanya data yang akurat mengenai suatu peristiwa atau kegiatan akan menghasilkan informasi yang berguna bagi pengambilan keputusan sehingga harus disimpan sebagai bukti, termasuk juga terhadap arsip suara yang terkumpul setelah Pemilu berlangsung, dengan kata lain adalah untuk menjamin keselamatan bahan pertanggungjawaban nasional tentang rencana, pelaksanaan dan penyelengaraan kehidupan kebangsaan, serta untuk menyediakan bahan pertanggungjawaban tersebut bagi pemerintah. ${ }^{11}$

Oleh sebab itu guna mewujudkan Pemilu yang demokratis perlu juga memperhatikan sistem kearsipan atau yang dikenal sebagai "filling system" yaitu suatu sistem, metode atau suatu cara yang dipergunakan dalam 
pengurusan dan penyimpanan arsip dengan mempergunakan suatu metode yang telah ditetapkan. Sistem pengarsipan yang baik akan bermanfaat bila dikelola secara teratur, namun juga akan menjadi masalah jika tidak dikelola secara teratur karena hanya menjadi tumpukan kertas yang tidak teratur.

Arsip berdasarkan fungsinya secara singkat dapat dibagi dalam Arsip Statis dan Arsip Dinamis. Arsip statis dan arsip dinamis dapat diuraikan secara singkat yaitu: ${ }^{12}$ arsip statis merupakan arsip yang sudah tidak dipergunakan secara langsung dalam kegiatan perkantoran sehari-hari namun tetap harus dikelola/ disimpan berdasarkan pertimbangan nilai guna yang terkandung di dalamnya. Sedangkan arsip dinamis. Adalah arsip yang digunakan secara langsung dalam kegiatan organisasi/ perkantoran sehari-hari. Arsip dinamis dibagi lagi kedalam 3 macam, yaitu:

a. Arsip aktif, ialah arsip yang masih sering digunakan bagi kelangsungan kerja;

b. Arsip semi aktif, yaitu arsip yang frekuensi penggunaannya sudah mulai menurun;

c. Arsip inaktif, adalah arsip yang jarang sekali dipergunakan dalam proses pekerjaan sehari-hari.

Selain berdasarkan pengertian di atas juga terdapat pengertian lain mengenai kearsipan, dalam Undang-Undang Kearsipan Nomor 43 Tahun 2009 pengertian jenisjenis arsip tersebut dapat dijelaskan secara singkat sebagai berikut: ${ }^{13}$ Arsip dinamis adalah arsip yang digunakan secara langsung dalam kegiatan pencipta arsip dan disimpan selama jangka waktu tertentu (sering disebut sebagai menerangi masa depan atau "lluminating the Future"). Arsip vital adalah arsip yang keberadaannya merupakan persyaratan dasar bagi kelangsungan operasional pencipta arsip, tidak dapat diperbarui, dan tidak tergantikan apabila rusak atau hilang. Arsip aktif adalah arsip yang frekuensi penggunaannya tinggi dan/atau terus menerus. Arsip inaktif adalah arsip yang frekuensi penggunaannya telah menurun. Arsip statis adalah arsip yang dihasilkan oleh pencipta arsip karena memiliki nilai guna kesejarahan (disebut sebagai petunjuk masa lalu atau "Guidance The Past"), telah habis retensinya, dan berketerangan dipermanenkan yang telah diverifikasi baik secara langsung maupun tidak langsung oleh Arsip Nasional Republik Indonesia dan/atau lembaga kearsipan, jadi dari primary sources sejarawan memperoleh dukungan bukti tentang apa yang sedang dikajinya, dan dari telaah sumber ditemukan sejumlah fakta bersama data pendukungnya. ${ }^{14}$ Pengertian lain adalah arsip sebagai salah satu sumber sejarah adalah catatan atau dokumen, dokumen sendiri mengandung pengertian sebagai sesuatu yang tertulis atau tercetak. Dokumen digunakan dalam arti sumber tertulis sebagai informasi sejarah adalah kebalikan dari kesaksian lisan, artifak, dan peninggalan arkeologis. Jadi, pengertian arsip mencakup pengertian dokumen yang tersimpan. ${ }^{15}$

2 http://www.duniaarsip.com/penggolongan-arsip-berdasarkan-fungsinya.html/ (diakses 25 Februari 2014).

13 Undang-Undang Republik Indonesia Nomor 43 Tahun 2009 Tentang Kearsipan. Lembaran Negara Republik Indonesia Nomor 152, Tambahan Lembaran Negara Republik Indonesia Nomor 5071

14 Mona Lohanda, Sumber Sejarah dan Penelitian Sejarah (Jakarta: Pusat Penelitian Kemasyarakatan dan Budaya Lembaga Penelitian UI Tahun 1990), hlm. 132.

15 Suhartono. "Penelitian Arsip". (Hand Out. Prodi Sejarah Fakultas Sastra Program Pascasarjana UGM), hlm. 20. 
Semangat dari Undang-Undang Kerasipan tersebut sesuai dengan reformasi birokrasi dan tata kelola pemerintahan yang baik "Good Governance", yang merupakan prioritas pertama dari sebelas prioritas Rencana Pembangunan Jangka Menengah Nasional (RPJMN) 2010-2014 dalam sistem perencanaan pembangunan nasional. Isu "Good Governance" mulai dianggap penting dan nyata, karena didorong oleh adanya dinamika yang menuntut perubahan-perubahan di sisi pemerintahan maupun di sisi warga negara, berbagai turunan dari istilah "Good Governance" (contoh: "civil society", partisipasi, transparansi, akuntabilitas) sering digunakan sebagai nama institusi/ organisasi maupun nama suatu program/proyek pemerintahan.

Di masa mendatang pemerintah dan pemimpin politikdinegarainidiharapkanmenjadi lebih demokratis, efisien dalam penggunaan sumber daya publik, efektif menjalankan fungsi pelayanan publik, lebih tanggap serta mampu menyusun kebijakan, program dan hukum yang dapat menjamin hak asasi dan keadilan sosial. Dengan mempertimbangkan sistem sosial yang ada serta serta kondisi praktek pemerintahan yang baik maka beberapa elemen yang dituntut dalam penyelenggaraan pemerintahan yang baik adalah: tipe kepemimpinan baru, kekuatan Civil Society, kemampuan teknis dan manajemen, ruang partisipasi, dan moral dan budaya demokrasi. ${ }^{16}$

Akses terhadap informasi sangat diperlukan termasuk penyebarluasan informasi, terutama informasi kearsipan dilakukan melalui media internet dalam rangka meningkatkan kinerja pemerintah melalui peningkatan anggaran untuk membuat jaringan antar instansi yang bertujuan akhir penerapan "e-government". Arsip yang otentik merupakan bukti dari akuntabilitas kinerja lembaga pemerintahan yang bersih dari KKN, hubungan dengan berbagai "stakeholders" khususnya partai politik, masyarakat, dan media secara terbuka dan akuntabel akan mempermudah dalam melakukan pengolahan data dan informasi yang terkandung dalam arsip yang ada.

Selain terhadap arsip yang disimpan tersebut juga dilakukan pemusnahan terhadap arsip yang tidak berguna untuk kepentingan operasional administrasi KPU, serta tidak memiliki nilai sejarah (baik bagi arsip di KPU propinsi, kabupaten/kota). Sebagai contoh terhadap arsip tersebut antara lain: Berupa surat suara/formulir kosong dan duplikasi berlebihan, laporan-laporan rutin penyelenggaraan Pemilu dan surat menyurat atau korespondensi yang bersifat rutin. Jenis arsip yang Pemilu maupun Pilkada yang mempunyai nilai sekunder atau berkelanjutan sebagai arsip statis (permanen) yang berfungsi untuk kepentingan sejarah dan penelitian, antara lain: ${ }^{17}$

a. Arsip Pemilu Anggota DPR, DPD, DPRD Propinsi, dan DPRD Kabupaten/Kota

Arsip tentang kebijakan dan regulasi, Desain dan film separasi (master) yang digunakan untuk membuat surat suara, daftar pemilih tetap, pengumuman dan laporan dana 
kampanye peserta Pemilu, hasil audit dari akuntan publik atas laporan dana kampanye, berita acara dan sertifikat hasil perhitungan suara di KPPS, berita acara dan sertifikat hasil perhitungan suara di PPS, PPK, KPU, kabupaten/kota, KPU propinsi, berita acara dan sertikat rekapitulasi hasil perhitungan suara di KPU, laporan hasil penetapan calon terpilih anggota DPR, DPD, dan DPRD Propinsi dan Kabupaten/kota kepada Presiden, sumpah/janji anggota DPR, DPD dan DPRD propinsi dan DPRD kabupaten kota, laporan penyelenggaraan Pemilu, penyelesaian sengketa kasus dalam Pemilu, berkas pelanggaran administrasi dalam Pemilu, berkas anggota DPR, DPD, dan DPRD propinsi, dan DPRD kabupaten/kota

b. Arsip pemilu Presiden dan Wakil Presiden Arsip regulasi, pedoman dan norma kegiatan Pemilu Presiden dan Wakil Presiden, desain dan film separasi (master) yang digunakan untuk membuat surat suara, daftar pemilih tetap, daftar pasangan calon, Pengumuman dan laporan dana kampanye peserta Pemilu, hasil audit dari akuntan publik atas laporan dana kampanye, berita acara dan sertifikat hasil perhitungan suara di PPS, PPK, KPU kabupaten/ kota, KPU propinsi dan KPU, berita acara dan sertifikat hasil perhitungan suara, laporan hasil penyelenggaraan Pemilu Presiden dan Wakil Presdien, pelantikan Presiden dan Wakil Presiden, laporan penyelenggaraan Pemilu, penyelesaian sengketa dalam Pemilu, berkas pelanggaran administrasi dalam Pemilu

c. Arsip Pemilihan Kepala Daerah dan Wakil Kepala Daerah

Surat pemberitahuan DPRD kepada KPUD mengenai berakhirnya masa jabatan kepala daerah, penetapan tata cara dan jadwal pelaksanaan Pilkada, pembentukan tim pengawas, PPK, PPS dan KPPS, daftar pemantau Pilkada, daftar pemilih tetap, penetapan tata cara pelaksanaan pendaftaran pemilih, penetapan dan pengumuman pasangan calon, jadwal pelaksanaan kampanye, penetapan tata cara pengenaan sanksi terhadap pelanggaran larangan pelaksanaan kampanye, laporan sumbangan dana kampanye, laporan hasil audit dana kampanye oleh akuntan publik, penetapan jumlah, lokasi, bentuk, dan tata letak TPS, penetapan jumlah, bahan, bentuk, ukuran, dan warna kotak suara, berita acara dan sertifikat hasil penghitungan suara di setiap KPPS, berkas sengketa/ kasus Pilkada, berita acara dan sertifikat rekapitulasi hasil penghitungan suara di PPS, PPK, KPU kabupaten/kota, KPU propinsi, keberatan terhadap hasil penghitungan suara, berita acara dan penetepan pasangan calon terpilih, pengangkatan dan pelantikan kepala daerah dan wakil kepala daerah

\section{Kelemahan Pengarsipan Arsip Pemilu Saat Ini, Dan Tolak Ukur Pengarsipan Yang Baik Bagi Pemilu}

\section{a. Kelemahan Pengarsipan Pemilu Saat ini}

Permasalahan pengarsipan tidak hanya terjadi dalam pengarsipan Pemilu, pengarsipan Kependudukan juga mengalami permasalahan yang rumit dan memerlukan penanganan yang didukung SDM yang memadai. Berikut beberapa permasalahan mengenai pengarsipan Pemilu yang dapat dikemukakan:

1) Kurangnya pengetahuan dalam pelaksanaan pengarsipan

Masih dirasa kurangnya pengetahuan dalam pengarsipan terjadi baik di pusat dan daerah, sehingga diperlukan Bimbingan Teknis yang 
simultan dari ANRI dan KPU dengan maksud menyelamatkan dan melestarikan arsip Pemilu baik Pemilu Kepala Daerah, Legislatif maupun Presiden. ANRI berkewajiban memberikan bantuan teknis dan sarana dan prasarana, sehingga arsip tersebut tersimpan dan teregistrasi dengan baik dan memudahkan untuk dilakukan pencarian kembali.

2) Fasilitas penyimpanan arsip yang minim Fasilitas penyimpanan arsip yang minim, terutama di daerah mengakibatkan banyaknya lembaga yang melakukan penyimpanan arsipnya secara sendiri-sendiri (mandiri) dan belum memanfaatkan tempat penyimpanan arsip yang terpusat. Oleh sebab itu penyimpanan arsip masih dilakukan dengan standar sendiri-sendiri, hal ini akan menyulitkan dalam usaha penelusuran kembali terhadap arsip (hal ini terkait dengan ketidak seragaman prosedur dan perlengkapan pengarsipan). Selain minimnya ruang, juga minimnya alat dan perlengkapan seperti: rak, filling cabinet, dan fasilitas komputer.

3) Penumpukan arsip yang membingungkan Penumpukan arsip akan menimbulkan pemandangan tidak enak dan akan merepotkan, oleh sebab itu dilakukan pemilahan dan penyimpanan arsip untuk kemudian dipergunakan sebagai alat pengambilan keputusan atau sebagai bahan pendukung kegiatan organisasi. Sebelum kiranya tumpukan arsip tersebut bercampur antara arsip aktif dan inaktif sehingga menimbulkan kesulitan dalam pencarian arsip.
4) Arsip Pemilu yang belum dipandang sebagaimana mestinya.

Kebanyakan dari masyarakat yang lebih memandang arsip sebagai suatu kertas semata, tanpa melihat sebagai suatu nilai informasi yang penting dan dapat dilihat dari sisi/prespektif kultural pada masa silam seperti terkait dengan demokrasi dan proses kegiatan Pemilu. Hal ini berkaitan juga dengan nilai ketepatan arsip kependudukan yang menjadi sumber masalah penetapan DPT (Daftar Pemilih Tetap).

\section{b. Tolak Ukur Pengarsipan Yang Baik Bagi Pemilu}

Keterkaitan mewujudkan Pemilu yang demokratis dengan proses pengarsipan memunculkan konteks arsip dinamis yang dianggap sebagai organik yang hidup, tumbuh dan terus berkembang seirama dengan tata kehidupan masyarakat maupun tata kelola pemerintahan. Fungsi dinamis kearsipan sebagai mana terdapat dalam Undang-Undang Kearsipan Nomor 43 Tahun 2009, dipengaruhi oleh teori-teori kearsipan yang dikemukakan oleh beberapa tokoh yang dapat dijelaskan secara singkat sebagai berikut: ${ }^{18}$

1) Teori Lingkaran Kehidupan Arsip

Teori ini dikemukakan oleh T.R. Schellenberg, pemikir ulung kearsipan dari Amerika "life cycle of records", teori ini menekankan penentuan nilai guna yang ada pada records, yakni nilai guna primer dan sekunder, dan nilai guna sekunder masih dibagi lagi menjadi nilai guna kebuktian dan informasional. Dalam metodologi ini, 
Schellenberg menekankan secara khusus akan tanggung jawab arsiparis untuk melakukan penilaian arsip dinamis yang bernilai sekunder, nilai guna riset, sehingga pembedaan antara arsip dinamis (records) dan arsip statis (archives) semakin jelas. Menurut Schellenberg, arsip atau "archives" adalah "those records of any public or private institution which are adjudged worthy of permanent preservation for reference and secondary pusposes" dapat diterjemahkan yaitu arsip adalah catatan-catatan dari setiap lembaga publik atau swasta yang diputuskan layak untuk dilestarikan secara permanen sebagai referensi dan tujuan sekunder. Bagi arsiparis, pencarian nilai guna riset merupakan kegiatan sentral dalam proses penilaian. Menurutnya nilai guna informasional dibagi menjadi :

- Bernilai Unik "Uniqueness": Informasi yang ada dalam arsip tidak ditemukan dalam rekaman informasi lainnya, sehingga bentuknya memang unik (misalnya, bukan hasil duplikasi),

- Bentuk Informasinya "Form": Seorang arsiparis haruslah mempertimbangkan bentuk informasinya (sejauh mana esensi tingkat informasinya tersirat) serta bentuk arsip itu sendiri (apakah ia dapat dengan mudah dibaca atau tidak oleh orang lain, misalnya arsip dalam bentuk punchcards, dan rekaman pita akan memerlukan alat bantu baca khusus), serta

- Mempertimbangkan Kebutuhan "Importance": Ketika melakukan peni- laian, seorang arsiparis pertama kali harus mempertimbangkan kebutuhan pemerintah itu sendiri, lalu kebutuhan para sejarawan/peneliti, maupun orang yang mempelajari ikatan-ikatan sosial dalam masyarakat atau "genealogists".

2) Teori Hermenetika/Teori Interpretasi

Tradisi Hermenetika, sebelum menjadi metode formal-ilmiah, dikenal sebagai kegiatan menerjemahkan dan mengartikan teks-teks atau kitab suci, terutama oleh kalangangereja.Metodehermenetikadipakai ketika berbicara mengenai pemahaman/ interpretasi/ penafsiran "verstehen". Pandangan dasar Hermenetika menganggap bahwa manusia adalah makhluk yang sepanjang hidupnya meng-eksternalkan apa yang terjadi dalam proses internal pikirannya dengan jalan menciptakan artefak-artefak budaya yang punya ciri-ciri objektif atau ciri kebendaan. Proses mengeksternalkan apa yang internal untuk menjadi sebuah objek berciri kebendaan ini dikenal sebagai "objektifikasi". ${ }^{19}$

3) Teori Penilaian Makro

Teori ini dikemukakan oleh Terry Cook, teori inimenekankandiperlukansuatu pendekatan yang logis dan terencana, para arsiparis yang dilibatkan dalam penilaian arsip perlu dibekali dengan suatu pemahaman terhadap pencipta arsip dinamis, tugas pokoknya dan fungsinya, strukturnya dan proses pembuatan keputusan, cara arsip dinamis tercipta, serta berbagai perubahan prosesproses ini sepanjang waktu. Kelebihan

Suprayitno, "Hubungan Ilmu Informasi Dengan Penilaian Arsip" (makalah), http://arsip.ugm.ac.id/buletindetil. php?id=69. (Diakses 10 Februari 2014). 
proses ini adalah bersifat teoretis dan praktis. Teoretis maksudnya mengidentifikasi fungsifungsi yang penting dalam masyarakat yang sebaiknya didokumentasikan, sementara praktis dalam arti ada kemampuan untuk menitikberatkan kegiatan penilaian arsip terhadap yang paling potensial bernilai guna kearsipan. Menurut Cook "the role of a archivist is not to impartially preserve of the whole of the records, but includes appraisal with the goal of finding those hot spots where the image of society is the most direct".

Dalam pengarsipan, ketidakberadaan dokumen tidak akan dapat tergantikan sebagaimana aslinya, dengan alat semodern dan teknologi secanggih apa pun, serta dengan menghabiskan biaya berapa pun banyaknya, tidak dapat mengembalikan suatu dokumen yang sudah telanjur musnah. Frank Boles (seorang arsiparis Amerika) mengatakan: "An archivist who destroys records does so with the assumption that the information within those documents will be lost forever".

Adapun suatu pengarsipan Pemilu yang baik harus menerapkan prinsip-prinsip sebagai berikut:

1) Sederhana

Pengarsipan Pemilu yang baik haruslah mudah dipahami dan diikuti bahkan oleh staf yang bukan ahli pengarsipan, sehingga tidak mempersulit diri karena arsip bukan hanya digunakan oleh ahli atau perencana arsip, tetapi juga dapat digunakan oleh masyarakat umum dan para praktisi yang bergerak dalam bidang penelitian dan bahkan sebagai bahan pembuktian dalam terjadinya suatu peristiwa atau kejadian.
2) Terjamin

Sistem pengarsipan Pemilu harus dapat menjamin kearsipannya bilamana diperlukan, oleh sebab itu arsip haruslah disimpan dalam tempat yang aman untuk menghindari arsip dari kerusakan yang dapat mengurangi nilai dan keakuratan arsip tersebut.

3) Lengkap dan padat

Walaupun sederhana namun juga pengarsipan Pemilu yang baik haruslah lengkap dan menyeluruh, sifat "sederhana" dan "lengkap" ini sering dianggap bertentangan, namun bisa diselesaikan dengan penjadwalan pemusnahan dan penghapusan arsip yang baik.

4) Penelusuran yang tersistem

Kearsipan yang baik disusun dalam kartu kendali, sebagai sarana pengendalian, penataan arsip (pola klasifikasi), dan penyusutan arsip. Kartu itu disusun dan diisi untuk memudahkan penelusuran.

5) Sistem klasifikasi yang memadai

Pengarsipan yang baik terdiri dalam berbagai klasifikasi dan tersusun dengan baik sebagai contoh tersusun dalam klasifikasi fungsi organisasi (fungsi fasilitatif dan fungsi substantif) dan klasifikasi masalah.

Pelestarian arsip dan data Pemilu akan memberikan informasi yang berguna bagi rakyat dan organisasi peserta Pemilu dan melindungi kepentingan negara dan hak pilih rakyat. Selain itu pengarsipan yang baik akan meningkatkan kualitas pelayanan publik di bidang pengarsipan, ini merupakan tugas KPU selain menyelesaikan sengketa Pemilu yang pada akhirnya akan membantu mewujudkan Pemilu yang adil. Dari berbagai paparan di atas akan menghasilkan 
proses pengarsipan Pemilu yang baik melalui proses:

1) Pendataan, penataan dan pendaftaran arsip; Pendataan digunakan untuk mengumpulan data tentang jenis arsip, jumlah, kurun waktu media serta kondisi arsip. Selanjutnya pendataan tersebut digunakan untuk merencanakan penataan yang akan menghasilkan kesatuan berkas arsip dan menghasilkan Daftar Pertelaahan Arsip (DPA). Lalu kemudian Daftar Pertelaahan Arsip ini yang akan digunakan untuk menemukan kembali arsip dan menyusutkan arsip yang telah selesai nilai gunanya. Serah terima dilakukan KPU propinsi/ kabupaten kota dengan mengajukan usul serah terima kepada Arsip Nasional Republik Indonesia

2) Penilaian Arsip dan Penyimpanan Arsip (dengan dibantu oleh Lembaga Kearsipan Daerah, dan Arsip Nasional Republik Indonesia);

Diadakan pemeriksaan kesesuaian daftar dengan fisik arsip, baik terhadap berkas arsip yang masih digunakan untuk kepentingan administrasi, pertanggung jawaban keuangan, kepentingan hukum dan disimpan di KPU sebagai arsip dinamis. Sedangkan arsip yang sudah tidak lagi digunakan sebagai kepentingan diatas, namun masih berguna bagi rekaman sejarah dan penelitian diserahkan kepada lembaga kearsipan daerah atau Arsip Nasional Indonesia sesuai kewenangannya dan menjadi arsip statis dan disimpan di lembaga kearsipan daerah maupun Arsip Nasional Indonesia. Terhadap berkas yang setelah dilakukan penilaian tidak memiliki nilai guna atau tidak memiliki nilai statis dikembalikan kepada KPU propinsi/kabupaten kota dan dimusnahkan sesuai dengan prosedur pemusnahan arsip.
Penyimpanan arsip dilakukan terhadap arsip yang masih digunakan untuk kepentingan administrasi KPU, KPU propinsi atau KPU kabupaten kota dan dibuatkan daftar arsip simpan.

3) Pengaksesan Arsip

Arsip yang pada saat dilakukan penilaian dinyatakan sebagai arsip statis pada dasarnya dapat diakses oleh masyarakat umum, dengan prosedur sesuai dengan peraturan perundangan yang berlaku dalam Undang-Undang Keterbukaan Informasi Publik dan terjadi saling melengkapi antara Undang-Undang KIP dan Undang-Undang Kearsipan. Dilakukan pembuatan proses salinan digital arsip oleh KPU, KPU propinsi/ KPU kabupaten kota bersama-sama dengan Arsip Nasional Indonesia Pusat dan Daerah karena pertimbangan reliabilitas dan otensitas dari copy digital arsip Pemilu. Hal tersebut dilakukan melalui sistem Jaringan Informasi Kearsipan Nasional atau JIKN dan jaringan informasi KPU yang berbasis internet.

4) Evaluasi dan Pelaporan Pengarsipan

Evaluasi dan pelaporan penyelamatan arsip Pemilu dilaksanakan bersama KPU, KPU propinsi/kabupaten kota bersama Arsip Nasional Republik Indonesia dilakukan untuk mengetahui tingkat pencapaian kegiatan, kendala, hambatan dan solusi pelaksanaan kegiatan sebagai bahan pertimbangan yang diperlukan untuk perbaikan pelaksanaan kegiatan selanjutnya.

\section{E. Penutup}

Dari hasil pembahasan di atas maka dapat ditarik Kesimpulan, yaitu, pertama, pengarsipan memiliki peran penting dalam menunjang proses Pemilu yang demokratis, karena sebagai 
salah satu bentuk kontrol atas jalannya Pemilu, di samping itu dokumen yang telah diarsipkan dapat menjadi alat bukti yang sah dan otentik, baik sebagai bukti sejarah maupun alat pembuktian di muka persidangan. Sehingga merevitalisasi pengarsipan arsip Pemilu merupakan tugas dari KPU yang penting untuk ditindaklanjuti.

Kedua, kelemahan pengarsipan saat ini selain faktor SDM juga sistem pengarsipan yang ada, hal ini ditandai dengan kurangnya pengetahuan dalam pelaksanaan pengarsipan, fasilitas penyimpanan arsip yang minim, penumpukan arsip yang membingungkan dan arsip Pemilu yang belum dipandang sebagaimana mestinya. Sehingga dari kelemahan tersebut diperlukan penataan kembali proses pengarsipan arsip pemilu dengan prinsip-prinsip yaitu: sederhana, penelusuran yang tersistem, lengkap dan padat, terjamin, sistem klasifikasi yang memadai, yang prinsip-prinsip tersebut diterapkan melalui mekanisme: Pendataan, penataan dan pendaftaran arsip; Penilaian Arsip dan Penyimpanan Arsip (dengan dibantu oleh Lembaga Kearsipan Daerah, dan Arsip Nasional Republik Indonesia); Pengaksesan Arsip; dan Evaluasi dan Pelaporan Pengarsipan.

Berdasarkan kesimpulan tersebut, maka yang perlu direkomendasikan adalah perlunya manajemen arsip yang baik dan diintegrasikan dengan teknologi informasi secara nasional dan terpadu ke dalam arsip elektronis yang komprehensif untuk meningkatkan keamanan dan kemudahan pengaksesan data secara cepat, otentik dan akurat oleh masyarakat. Juga perlu dibangun suatu jaringan komunikasi elektronik yang memadai, termasuk dengan sekretariat KPU di propinsi sehingga tercipta WAN (Wide Area Network) dengan terlebih dahulu melakukan pengadaan server dan pembaharuan komputer kerja dengan menggunakan software pengolahan data yang baik.

Pengaturan lebih lanjut mengenai pengarsipan Pemilu selain pemuktahiran data dan sarana pengolah data, juga perlunya hukum yang memadai sehingga diharapkan kesesuaian dengan berbagai undang-undang terkait seperti Undang-Undang Keterbukaan Informasi Publik Nomor 14 Tahun 2008 dimana dalam undangundang tersebut dinyatakan bahwa informasi publik bersifat terbuka dan dapat diakses oleh pengguna sistem informasi publik, disamping perlu peningkatan SDM di KPU yang memahami pengelolaan kearsipan baik di Kabupaten/Kota.

\section{DAFTAR PUSTAKA}

Buku

Basuki, Sulistyo, Manajemen Arsip Dinamis Pengantar Memahami dan Mengelola Informasi dan Dokumen, (Jakarta: Gramedia, 2003).

Fahmi, Khairul, Pemilihan Umum dan Kedaulatan Rakyat (Jakarta: PT. Raja Grafindo Persada, 2011).

Liddle, R William, Pemilu-Pemilu Orde Baru: Pasang Surut Kekuasaan Politik (Jakarta: Lembaga Penelitian, Pendidikan dan Penerangan Ekonomi dan Sosial, 1992).

Lohanda, Mona, Sumber Sejarah dan Penelitian Sejarah (Jakarta: Pusat Penelitian Kemasyarakatan dan Budaya Lembaga Penelitian UI, 1990).

Nazir, Metode Penelitian (Jakarta: Rineka Cipta, 1998)

Rizkiansyah, Mengawal Pemilu Menatap Demokrasi (Bandung: Idea Publishing, 2007).

Sedarmayanti, Tata Kearsipan dengan Memanfaatkan Teknologi Modern (Bandung: Mandar Maju, 2003).

Sumartono, Hetifah Sj, Inovasi, Partisipasi dan Good Governance (Jakarta: Yayasan Obor Indonesia, 2003).

\section{Makalah / Artikel / Prosiding / Hasil Penelitian}

Budiarti, Idha, "Sistem dan Pelaksanaan Pemilu Anggota DPR, DPD dan DPRD Tahun 2014", (makalah disampaikan pada kegiatan CLE 
Badan Pembinaan Hukum Nasional, Jakarta, 18 Februari 2014).

Nuryani, Anna Nunuk, "Arsip Pemilu Legislatif dan Pemilu Presiden Harus Segera Diselamatkan," http://www.bpadjogja.info/post/berita/302/ arsip-pemilu-legislatif-dan-pemilu-presidenharus-segera-diselamatkan-.html (diakses 25 Februari 2014).

Suhartono, "Penelitian Arsip". Hand Out. (Prodi Sejarah Fakultas Sastra Program Pascasarjana UGM).

\section{Internet}

Antara News Jawa Timur,"Data Penting Pemilu Kabupaten Malang Hilang Dicuri", http://www. antarajatim.com/lihat/berita/123119/datapenting-pemilu-kabupaten-malang-hilangdicuri (diakses 10 Februari 2014).

Komisi Pemilihan Umum Republik Indonesia, "Tugas dan Kewenangan KPU" http://www.kpu.go.id/ index.php?option $=$ com_content\&task=view\&id =35\&Itemid=62 (diakses 10 Februari 2014).
Suprayitno, "Hubungan Ilmu Informasi Dengan Penilaian Arsip", http://arsip.ugm.ac.id/ buletindetil.php?id=69, (diakses 10 Februari 2014).

www.duniaarsip.com, "Penggolongan Arsip Berdasarkan Fungsinya", http://www.duniaarsip. com/penggolongan-arsip-berdasarkanfungsinya.html/ (diakses 25 Februari 2014).

\section{Peraturan}

Undang-Undang Nomor 15 Tahun 2011 tentang Penyelenggaraan Pemilu. Lembaran Negara Republik Indonesia Nomor Tahun 2007 Nomor 59. Tambahan Lembaran Negara Republik Indonesia Nomor 4721.

Undang-Undang Republik Indonesia Nomor 43 Tahun 2009 Tentang Kearsipan. Lembaran Negara Republik Indonesia Nomor 152, Tambahan Lembaran Negara Republik Indonesia Nomor 5071.

Peraturan Kepala Arsip Nasional tentang Pedoman, Pendataan, Penataan dan Penyimpanan Dokumen/Arsip Pemilu Nomor 8 Tahun 2005. 